\title{
Effects of Hallucinogens on Locomotor and Investigatory Activity and Patterns: Influence of $5-\mathrm{HT}_{2 \mathrm{~A}}$ and $5-\mathrm{HT}_{2 \mathrm{C}}$ Receptors
}

Kirsten Krebs-Thomson, Ph.D., Martin P. Paulus, M.D., and Mark A. Geyer, Ph.D.

The 5- $\mathrm{HT}_{2 \mathrm{~A}}$ and $5-\mathrm{HT}_{2 \mathrm{C}}$ antagonists $\mathrm{MDL} 100,907$ and SER-082 were tested with the $5-H T_{2 A / C}$ agonist DOI and the 5-HT $\mathrm{T}_{1 \mathrm{~A} / 2 \mathrm{~A} / 2 \mathrm{C}}$ agonist LSD in the Behavioral Pattern Monitor, which provides multiple measures of locomotor and investigatory activity. Previous investigations have shown that these measures load onto three independent behavioral factors: amount of activity, exploratory behavior, and behavioral organization. Rats pretreated with saline, MDL 100,907 (0.25-2.0 mg/kg), or SER-082 (0.5-1.0 mg/kg) were treated with saline, $0.25 \mathrm{mg} / \mathrm{kg}$ DOI, or $60 \mu \mathrm{g} / \mathrm{kg}$ LSD. All effects of DOI were blocked by all doses of MDL
100,907, but only by the highest dose of SER-082. While the effects of LSD on activity and exploratory behavior were largely unaffected, either pretreatment antagonized the effects of LSD on behavioral organization. Thus, all of these effects of DOI were attributable to $5-\mathrm{HT}_{2 A}$ receptors, whereas the effect of LSD on behavioral organization was influenced by both $5-\mathrm{HT}_{2 A}$ and $5-\mathrm{HT}_{2 \mathrm{C}}$ receptors.

[Neuropsychopharmacology 18:339-351, 1998]

(C) 1998 American College of Neuropsychopharmacology. Published by Elsevier Science Inc.

elaboration of the underlying substrate(s) mediating the hallucinogenic effects, however, has been absent, due to the lack of selective ligands.

Recently it has become possible to discriminate further between the subtypes of $5-\mathrm{HT}_{2}$ receptors, such as $5-\mathrm{HT}_{2 \mathrm{~A}}$ (formerly called simply $5-\mathrm{HT}_{2}$ ) and $5-\mathrm{HT}_{2 \mathrm{C}}$ (previously called $5-\mathrm{HT}_{1 \mathrm{C}}$ ). The $5-\mathrm{HT}_{2 \mathrm{~A}}$ antagonist $\mathrm{MDL}$ 100,907 has a high selectivity for $5-\mathrm{HT}_{2 \mathrm{~A}}$ receptors and has been reported to have a 100- to 300 -fold greater selectivity for $5-\mathrm{HT}_{2 \mathrm{~A}}$ receptors than for $5-\mathrm{HT}_{2 \mathrm{C}}$ receptors (Carr et al. 1991; Palfreyman et al. 1993; Johnson et al. 1996; Kehne et al. 1996). The 5- $\mathrm{HT}_{2 \mathrm{C}}$ antagonist SER-082 has been reported to have a 40 -fold selectivity for $5-\mathrm{HT}_{2 \mathrm{C}}$ receptors over $5-\mathrm{HT}_{2 \mathrm{~A}}$ receptors and other sites (Nozulak et al. 1995). Using these selective antagonists it is possible to examine the roles these receptor subtypes play in the behavioral effects of the hallucinogens.

To examine the effects of MDL 100,907 and SER-082 alone and in combination with both the $5-\mathrm{HT}_{2 \mathrm{~A} / \mathrm{C}}$ agonist DOI and the mixed 5- $\mathrm{HT}_{1 \mathrm{~A} / 2 \mathrm{~A} / 2 \mathrm{C}}$ agonist LSD, we tested the effects of these drugs on rats in our Behavioral Pattern Monitor (BPM). The BPM is an activity and 
holeboard chamber that enables analyses of quantitative and qualitative changes in patterns of locomotor and investigatory activity (Geyer 1990). Hallucinogens have characteristic effects on locomotor and exploratory behavior in rats exposed for the first time to the BPM. Specifically, hallucinogens decrease both locomotor activity and investigatory holepokes (Geyer and Krebs 1994; Adams and Geyer 1982, 1985). In addition, hallucinogens increase the avoidance of the central portion of the BPM chamber. This pattern of behavior has been described as an hallucinogen-induced potentiation of neophobia and agoraphobia because of the increased avoidance of novel and central areas (Geyer and Krebs 1994; Adams and Geyer 1982, 1985). In addition to LSD, both phenalkylamine and indoleamine hallucinogens produce similar behavioral profiles, while a variety of other psychoactive drugs produce different behavioral profiles in this paradigm (Geyer and Krebs 1994).

These characteristic effects of hallucinogens can be modulated by pretreatment with 5-HT antagonists. The effects of DOI and LSD in the BPM system have been evaluated with nonselective 5-HT antagonists. For the phenalkylamine hallucinogen DOI, pretreatment with the 5- $\mathrm{HT}_{2 \mathrm{~A} / \mathrm{C}}$ antagonist ritanserin blocked the effects of DOI. Ritanserin failed to antagonize, however, the effects of LSD (Mittman and Geyer 1991). Hence, although it appears that the effects of DOI and the BPM paradigm are attributable to $5-\mathrm{HT}_{2 \mathrm{~A} / \mathrm{C}}$ receptors, the possibility that $5-\mathrm{HT}_{2 \mathrm{~A} / \mathrm{C}}$ receptors do not influence the effects of LSD needed further study.

The following experiments were designed to elucidate the respective roles of $5-\mathrm{HT}_{2 \mathrm{~A}}$ and $5-\mathrm{HT}_{2 \mathrm{C}}$ receptors in the behavioral effects of DOI and LSD in the BPM. The hypothesis was tested that $5-\mathrm{HT}_{2 \mathrm{~A}}$, but not $5-\mathrm{HT}_{2 \mathrm{C}}$, receptors contribute to the effects of DOI. It was unknown whether $5-\mathrm{HT}_{2 \mathrm{~A}}$ or $5-\mathrm{HT}_{2 \mathrm{C}}$ antagonism would attenuate the effects of LSD.

\section{METHODS}

\section{Animals}

A total of 270 naive male Sprague-Dawley rats (Harlan Industries, San Diego, CA) were housed two or three per cage under a 12 hour reverse light cycle (lights off: $0700 \mathrm{~h}$ ). Food and water were available ad libitum. Weights ranged from 300 to $400 \mathrm{~g}$. Animals were allowed to acclimatize for approximately 1 week after arrival.

\section{Behavioral Testing}

All behavior was measured in the Behavioral Pattern Monitor (BPM), a $30.5 \times 61.0 \mathrm{~cm}$ black Plexiglas chamber. Ten $2.5-\mathrm{cm}$ holes were placed in the chamber (three in each long wall, one in one short wall, and three in the floor). Photocells in each hole detected investigatory nosepokes (holepokes). A touchplate, $15.2 \mathrm{~cm}$ above the floor, allowed detection of rearings when contact was made by the animal between the metal floor and the metal touchplate. A $4 \times 8$ array of photobeams was used to define the animal's position in an $X-Y$ coordinate system with a resolution of $3.8 \mathrm{~cm}$. Chambers were kept dark with the exception of 7.5-watt red lights. An IBMPC-compatible computer monitored the status of all photobeams and recorded the duration and nature of all changes with a temporal resolution of $55 \mathrm{~ms}$ and stored the data for later analysis.

\section{Analysis}

The following variables were obtained from the raw data from: the $X$ and $Y$ coordinates of the rat in the chamber; the occurrence of holepokes or rearings; and the amount of time spent at a particular coordinate or performing a particular behavior. A detailed description of the analyses of locomotor patterns can be found in Paulus and Geyer (1993). As specified below, measures of locomotor and investigatory activity and patterns were assessed by examining several aspects of activity: the number of micro-event counts during a given time resolution; the temporal scaling exponent $\alpha$; the spatial scaling exponent $\mathrm{d}$; the dynamical entropy $\mathrm{h}$; the $\%$ rears/counts; and the \% holepokes/counts measures. The counts measure corresponds to the number of photobeam breaks in the BPM. The temporal scaling exponent $\alpha$ measures the frequency of micro-event counts to the duration of the micro-event, which provides a ratio of short duration micro-events to long duration microevents. The spatial scaling exponent $\mathrm{d}$ describes the geometrical characteristics of movements, based on the length of a sequence of micro-events to the resolution with which the sequence is observed. Thus, a low $\mathrm{d}$ value indicates relatively straight or smooth movements, whereas a high $\mathrm{d}$ value indicates relatively circumscribed or rough movements. The dynamical entropy $h$ measure is based on the assessment of the uncertainty generated by chaotic nonlinear dynamical systems and gives a measure of the degree of unpredictability of future movements. Thus, a low $\mathrm{h}$ value indicates highly predictable movement sequences, whereas a high $h$ value indicates a large variety of different movement sequences. Investigatory activity was assessed by recording the number of rearings and holepokes in the BPM. These measures were corrected for the amount of activity by dividing the measure by the number of counts and were expressed in percentage values to give the $\%$ rears/counts and the \% holepokes/counts measures. Previous factor analysis of these measures in drug-naive rats revealed that three independent factors accounted for the majority of the variance (Paulus and Geyer 1993). These factors have been described as the amount of activity factor, the exploratory behavior factor, and the be- 
havioral organization factor. The amount of activity factor loaded primarily on the counts and $\alpha$ measures. The exploratory behavior factor loaded on the \% rears/ counts and \% holepokes/counts measures. The behavioral organization factor loaded primarily on the spatial $\mathrm{d}$ and dynamical entropy $\mathrm{h}$ measures. These three factors are used to characterize the amount and structure of rat locomotor and investigatory activity in the BPM.

Data were examined in $30 \mathrm{~min}$ time resolutions and analyzed using two-way ANOVA with time as a repeated measure. Specific post hoc comparisons between selected groups were done using Newman-Keuls. All significances are reported for $\alpha<0.05$.

\section{Procedure}

Animals were tested in the dark and during the dark phase of their light cycle. On the day prior to testing, animals were taken to the testing room, weighed, handled briefly, placed in a clear Plexiglas box $(24 \mathrm{~cm} \times 46 \mathrm{~cm})$ for $30 \mathrm{~s}$, and then returned to their cages in the animal room. For each experimental session, naive animals were brought to the testing room and allowed to sit for
$60 \mathrm{~min}$ before being given pretreatment injections under red lights in the testing room. Test injections were administered $20 \mathrm{~min}$ later and, after $10 \mathrm{~min}$, animals were placed in the BPM chamber for testing. Data were collected for 60 min during the dark phase of the animals' light/dark cycle. The chambers were cleaned thoroughly between testing sessions.

\section{Drugs}

Drugs used were: 1(2,5-dimethoxy-4-iodophenyl)-2-aminopropane (DOI; Research Biochemicals Inc., Natick, MA); $d$-lysergic acid diethylamide (LSD; National Institute on Drug Abuse, Rockville, MD); (R)-(+)- $\alpha$-(2,3-dimethoxyphenyl)-1-[2-(fluorophenyl)ethyl]-4-piperidinemethanol (MDL 100,907; Hoechst Marion Roussel, Cincinnati, OH); (+)-cis-4,5,7a, 8,9,10,11,11a-Octahydro-7H-10methylindol [1,7-bc][2,6]-naphthyridine (SER-082; Novartis, Basel, Switzerland). DOI, LSD, and SER-082 were dissolved in saline. MDL 100,907 was dissolved in a solution of Tween 80 and saline. All drugs were administered in a volume of $1 \mathrm{ml} / \mathrm{kg}$ subcutaneously.

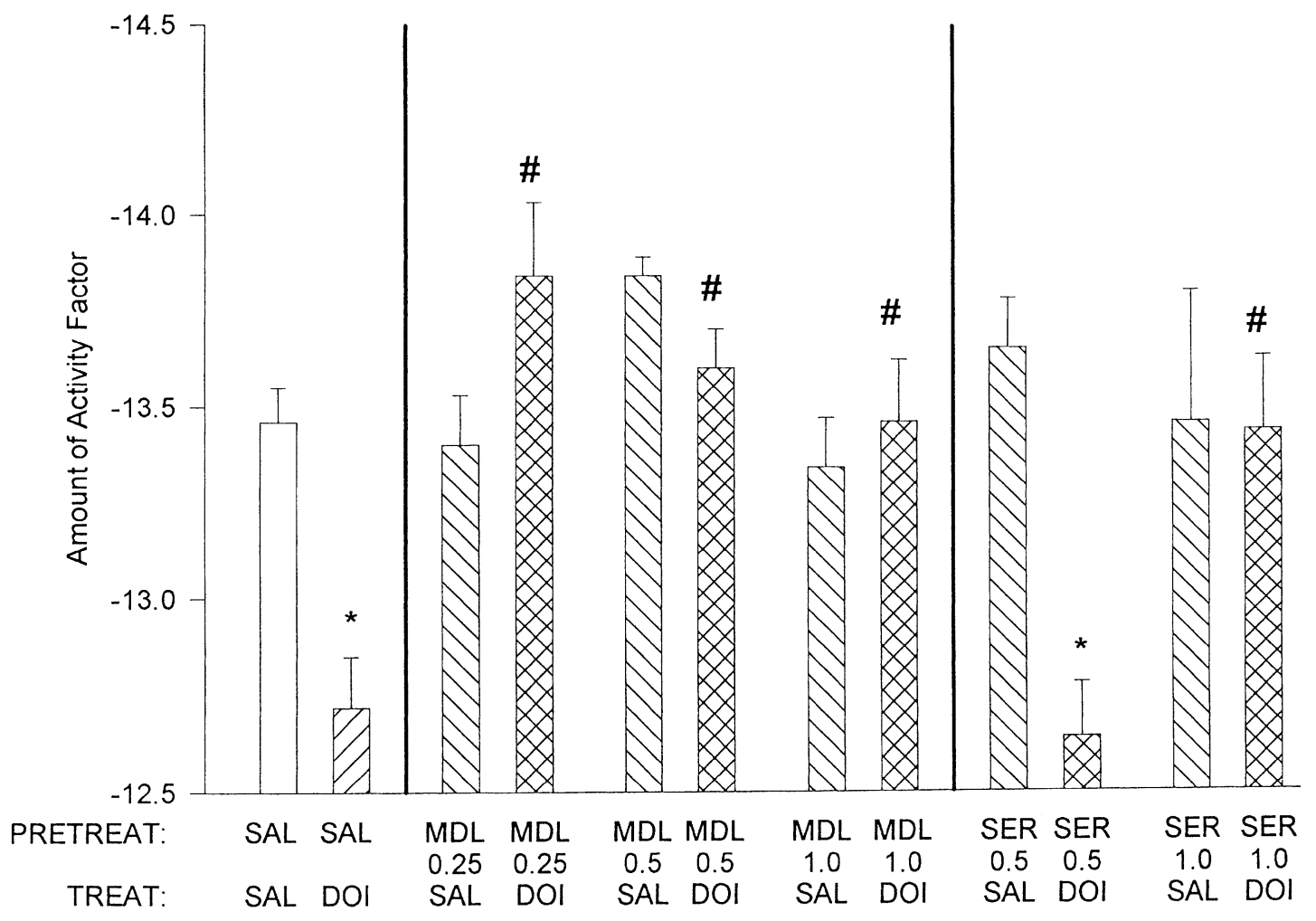

Figure 1. DOI $(0.25 \mathrm{mg} / \mathrm{kg})$ treatment significantly decreased the amount of activity factor, a complex measure of locomotor activity. This decrement was attenuated significantly by either $0.25,0.5$, or $1.0 \mathrm{mg} / \mathrm{kg}$ MDL 100,907 pretreatment, indicating antagonism. Only the highest dose of SER-082 pretreatment attenuated this effect. Data are presented as group means \pm SEM for the first time 30 min of testing in the BPM. ${ }^{*} p<.05$, group is different from its saline control group. \# $p<.05$, group is different from SAL/DOI group. 


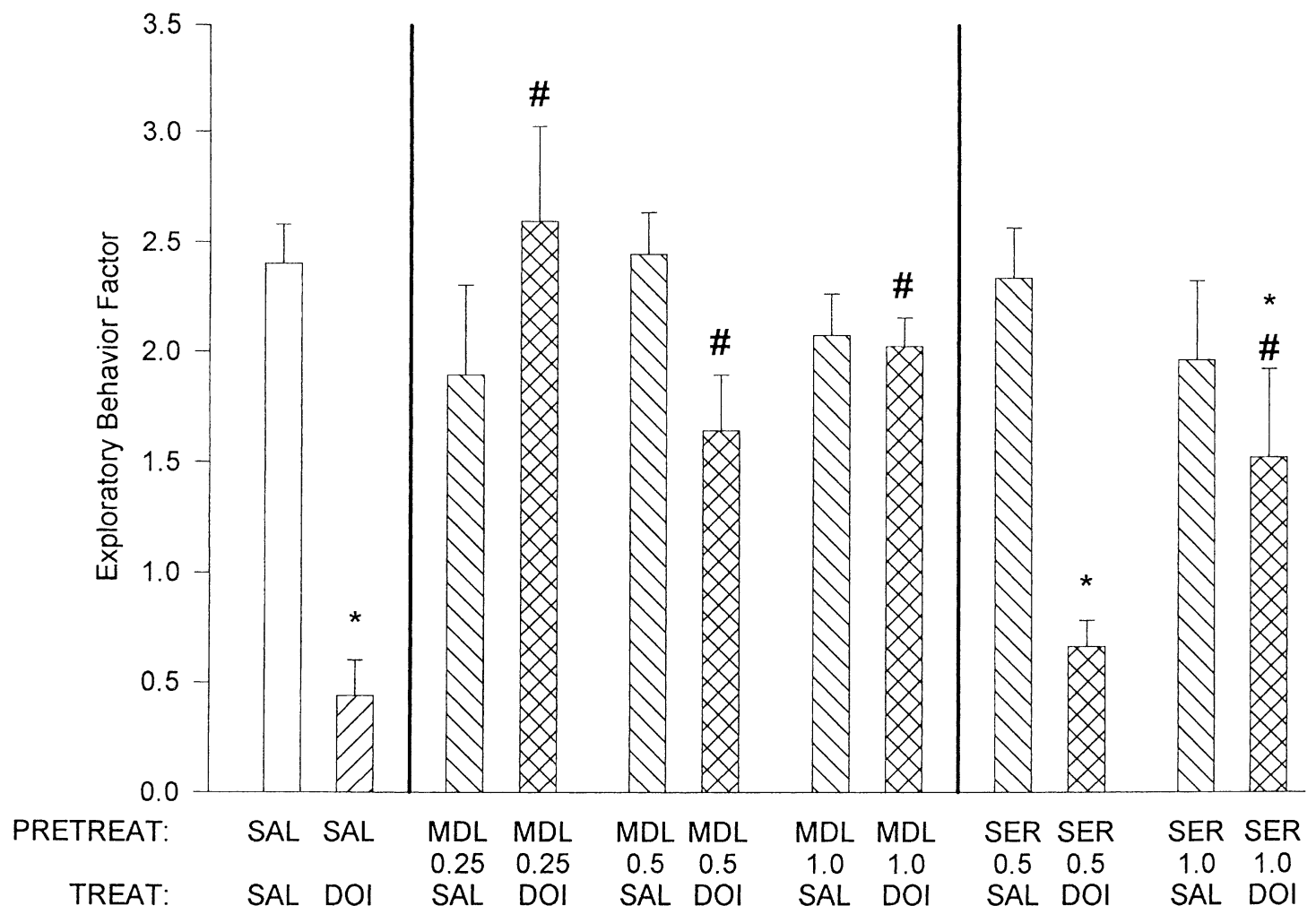

Figure 2. DOI $(0.25 \mathrm{mg} / \mathrm{kg})$ treatment significantly decreased the exploratory behavior factor, a complex measure of investigatory activity. This decrement was attenuated significantly by $0.25-1.0 \mathrm{mg} / \mathrm{kg}$ MDL 100,907 pretreatment, indicating antagonism. Only the highest dose of SER-082 pretreatment attenuated this effect. Data are presented as group means \pm $\mathrm{SEM}$ for the first $30 \mathrm{~min}$ of testing in the BPM. ${ }^{*} p<.05$, group is different from its saline control group. \# $p<.05$, group is different from SAL/DOI group.

\section{EXPERIMENT 1}

\section{Procedure}

Eighty-one rats were pretreated with either saline, 0.25, 0.5 , or $1.0 \mathrm{mg} / \mathrm{kg}$ MDL 100,907 . Then rats were treated with either saline or $0.25 \mathrm{mg} / \mathrm{kg}$ DOI. These doses were selected from previous studies (Krebs-Thomson and Geyer 1996; Sipes and Geyer 1995). The eight groups ( $n=$ 6-17) were tested for $60 \mathrm{~min}$.

\section{Results and Discussion}

There were significant interactions between MDL 100,907 and DOI over the hour of testing for the amount of activity factor $[\mathrm{F}(3,73)=7.75]$, the exploratory behavior factor $[\mathrm{F}(3,73)=10.71]$, and the behavioral organization factor $[\mathrm{F}(3,73)=5.86]$. There was also a significant interaction with time for the amount of activity factor (time $\times$ DOI $[F(1,73)=5.30])$. These data were further examined for the first $30 \mathrm{~min}$ of testing, a time resolution previously used in a similar experiment (Mittman and Geyer 1991).

There were significant interactions between MDL
100,907 pretreatment and DOI treatment for the initial $30 \mathrm{~min}$ of testing for the amount of activity factor $[\mathrm{F}(3,73)=$ 8.22], the exploratory behavior factor $[\mathrm{F}(3,73)=13.97]$, and the behavioral organization factor $[\mathrm{F}(3,73)=7.14]$, indicating that the effects produced by $0.25 \mathrm{mg} / \mathrm{kg}$ DOI were altered by MDL 100,907.

Specific comparisons revealed that the acute administration of DOI significantly reduced all three factors in saline-pretreated rats, indicated by the asterisk $\left(^{*}\right)$ symbols (Figures 1-3). There was no significant difference between any of the MDL 100,907-pretreated (MDL/ SAL) groups and the SAL/SAL group for any factor, indicating that there was no significant pretreatment effect of MDL 100,907 alone. All doses of MDL 100,907 pretreatment successfully antagonized the effects of DOI on all three factors, as evidenced by the significant difference between the respective MDL/DOI and SAL/ DOI groups, indicated by the pound (\#) symbol in Figures 1-3.

Note that in the simple behavioral measures themselves, such as movements (analogous to counts), holepokes, and spatial d (Table 1), MDL 100,907 pretreatment successfully antagonized the effects of DOI on movements 


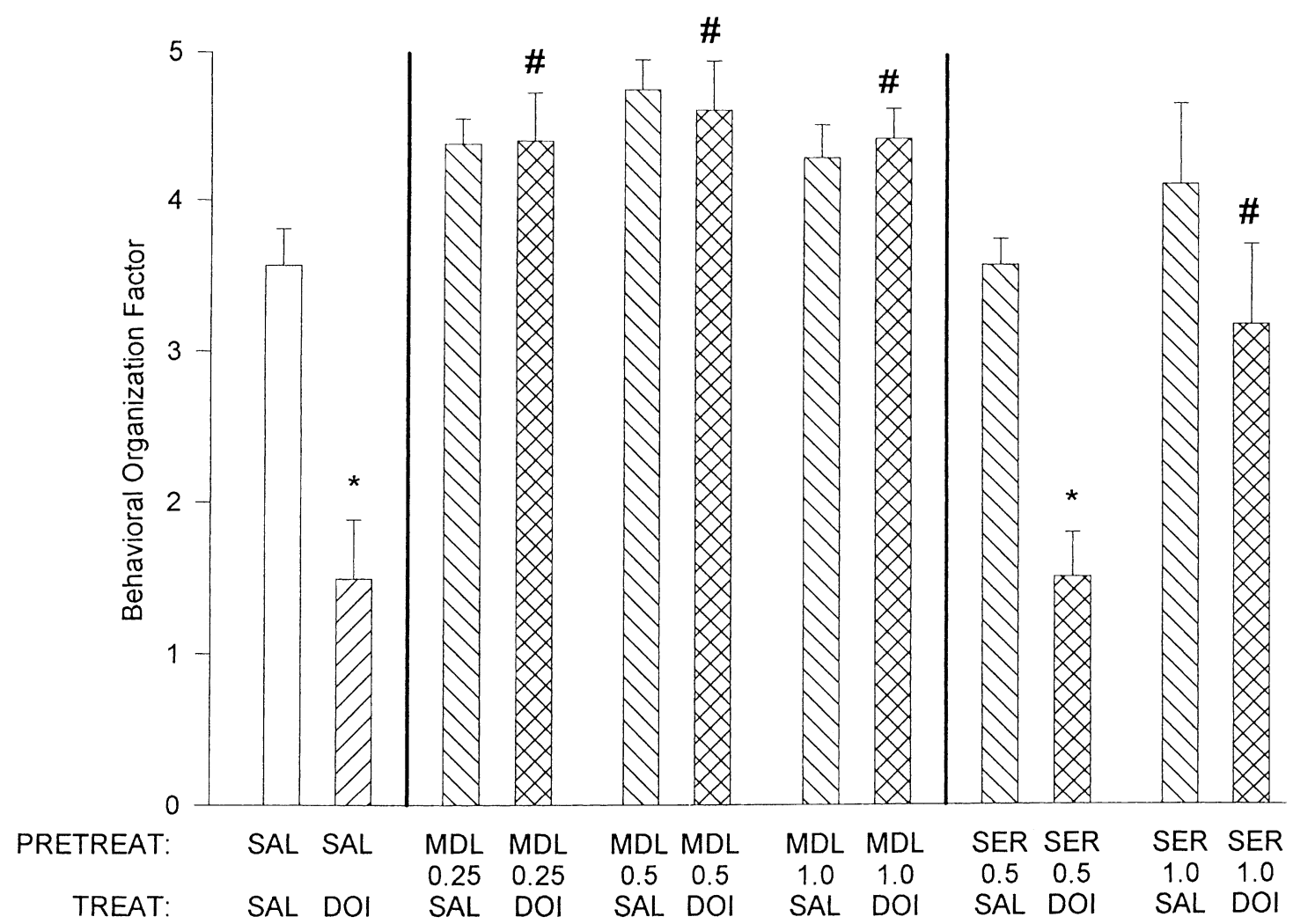

Figure 3. DOI $(0.25 \mathrm{mg} / \mathrm{kg})$ treatment significantly decreased the behavioral organization factor, a measure of the structure of the locomotor pattern. This decrement indicates an increase in the smoothness and predictability of the locomotor pattern. This effect of DOI was attenuated significantly by $0.25,0.5$, or $1.0 \mathrm{mg} / \mathrm{kg}$ MDL 100,907 pretreatment, indicating antagonism. Only the highest dose of SER-082 pretreatment attenuated this effect. Data are presented as group means \pm SEM for the first $30 \mathrm{~min}$ of testing in the BPM. ${ }^{*} p<.05$, group is different from its saline control group. \# $p<.05$, group is different from SAL/DOI group.

at the highest dose, on holepokes at the lowest and the highest dose, and on spatial $\mathrm{d}$ at every dose, indicated by the pound symbols in Table 1. These behaviors are exhibited to demonstrate that they are roughly analogous to the factors, but that the factors provide more robust results.

Thus, acute treatment with $0.25 \mathrm{mg} / \mathrm{kg}$ DOI decreased measures of amounts of activity, of exploratory behavior, and of behavioral organization, such that patterns of activity exhibited smoother, more predictable locomotor paths. These effects were antagonized by every dose of MDL 100,907 pretreatment.

\section{EXPERIMENT 2}

\section{Procedure}

Sixty-eight rats were pretreated with either saline, 0.5 , or $1.0 \mathrm{mg} / \mathrm{kg}$ SER-082. Then rats were treated with either saline or $0.25 \mathrm{mg} / \mathrm{kg}$ DOI. These doses were selected from Experiment 1 and previous studies (KrebsThomson and Geyer 1996; Sipes and Geyer 1995; Nozulak et al. 1995). The six groups $(n=7-17)$ were tested for $60 \mathrm{~min}$. Data from the SAL/SAL and SAL/DOI groups were shared with Experiment 1.

\section{Results and Discussion}

Based on results from Experiment 1, the following data were examined for the initial $30 \mathrm{~min}$ of testing. There were significant interactions between SER-082 pretreatment and DOI treatment for the initial $30 \mathrm{~min}$ of testing for the amount of activity factor $[\mathrm{F}(2,62)=3.89]$ and the exploratory behavior factor $[\mathrm{F}(2,62)=5.48]$.

Specific comparisons revealed that there was no significant difference between any of the SER-082-pretreated (SER/SAL) groups and SAL/SAL groups for any factor, indicating that there was no significant pretreatment effect of SER-082 alone. Only the highest dose of SER-082 pretreatment successfully antagonized the effects of DOI on all three factors, as evidenced by the significant difference between the respective SER/DOI and SAL/DOI groups, indicated by the pound symbol in Figures 1-3. 
Table 1.

\begin{tabular}{|c|c|c|c|}
\hline Group (n) & Movements & Holepokes & Spatial d \\
\hline \multicolumn{4}{|l|}{ Experiment 1} \\
\hline SAL/SAL (17) & $1163 \pm 59$ & $128 \pm 12$ & $1.577 \pm 0.013$ \\
\hline SAL/DOI (17) & $832 \pm 49^{*}$ & $37 \pm 6^{*}$ & $1.471 \pm 0.021^{*}$ \\
\hline MDL $0.25 /$ SAL (7) & $1042 \pm 62$ & $127 \pm 20$ & $1.631 \pm 0.010$ \\
\hline MDL $0.25 /$ DOI (7) & $891 \pm 53^{*}$ & $121 \pm 20 \#$ & $1.624 \pm 0.017 \#$ \\
\hline MDL $0.5 /$ SAL (7) & $962 \pm 33$ & $121 \pm 15$ & $1.645 \pm 0.013$ \\
\hline MDL $0.5 / \mathrm{DOI}(6)$ & $984 \pm 60$ & $69 \pm 8^{*}$ & $1.640 \pm 0.020 \#$ \\
\hline MDL 1.0/SAL (10) & $1114 \pm 56$ & $88 \pm 10$ & $1.622 \pm 0.012$ \\
\hline MDL 1.0/DOI (10) & $1073 \pm 47 \#$ & $100 \pm 11 \#$ & $1.630 \pm 0.012 \#$ \\
\hline \multicolumn{4}{|l|}{ Experiment 2} \\
\hline SER 0.5/SAL (10) & $1192 \pm 74$ & $97 \pm 8^{*}$ & $1.573 \pm 0.009$ \\
\hline SER 0.5/DOI (10) & $793 \pm 51^{*}$ & $35 \pm 2^{*}$ & $1.473 \pm 0.016^{*}$ \\
\hline SER 1.0/SAL (7) & $960 \pm 95$ & $87 \pm 19^{*}$ & $1.613 \pm 0.029$ \\
\hline SER 1.0/DOI (7) & $903 \pm 80^{*}$ & $83 \pm 21 \#$ & $1.559 \pm 0.028 \#$ \\
\hline \multicolumn{4}{|l|}{ Experiment 3} \\
\hline SAL/SAL (27) & $1171 \pm 44$ & $115 \pm 8$ & $1.597 \pm 0.10$ \\
\hline SAL/LSD (27) & $685 \pm 54^{*}$ & $28 \pm 3^{*}$ & $1.488 \pm 0.13^{*}$ \\
\hline MDL $0.25 /$ SAL (7) & $864 \pm 123^{*}$ & $133 \pm 13$ & $1.653 \pm 0.19$ \\
\hline MDL $0.25 / \operatorname{LSD}(7)$ & $696 \pm 111^{*}$ & $67 \pm 15^{*}$ & $1.658 \pm 0.20 \#$ \\
\hline MDL 0.5/SAL (7) & $1109 \pm 45$ & $122 \pm 14$ & $1.642 \pm 0.19$ \\
\hline MDL $0.5 / \operatorname{LSD}(7)$ & $540 \pm 90^{*}$ & $36 \pm 10^{*}$ & $1.681 \pm 0.17^{*} \#$ \\
\hline MDL 1.0/SAL (10) & $1009 \pm 28$ & $107 \pm 14$ & $1.621 \pm 0.12$ \\
\hline MDL 1.0/LSD (10) & $679 \pm 90^{*}$ & $62 \pm 16^{*}$ & $1.650 \pm 0.12 \#$ \\
\hline MDL 2.0/SAL (10) & $1026 \pm 66$ & $110 \pm 18$ & $1.625 \pm 0.11$ \\
\hline MDL 2.0/LSD (10) & $741 \pm 81^{*}$ & $58 \pm 11^{*}$ & $1.616 \pm 0.13 \#$ \\
\hline \multicolumn{4}{|l|}{ Experiment 4} \\
\hline SER 0.5/SAL (10) & $1101 \pm 44$ & $94 \pm 13$ & $1.571 \pm 0.19$ \\
\hline SER 0.5/LSD (10) & $461 \pm 42^{* \dagger}$ & $20 \pm 3^{*}$ & $1.590 \pm 0.03 \#$ \\
\hline SER 1.0/SAL (6) & $1012 \pm 64$ & $78 \pm 17^{*}$ & $1.581 \pm 0.22$ \\
\hline SER 1.0/LSD (7) & $358 \pm 58^{*+}$ & $24 \pm 6^{*}$ & $1.591 \pm 0.24 \#$ \\
\hline
\end{tabular}

Effect of either saline, $0.25,0.5,1.0$, or $2.0 \mathrm{mg} / \mathrm{kg}$ MDL 100,907, 0.5 or $1.0 \mathrm{mg} / \mathrm{kg}$ SER-082 pretreatment on the effects of either saline, $0.25 \mathrm{mg} / \mathrm{kg}$ DOI, or $60 \mu \mathrm{g} / \mathrm{kg}$ LSD treatment on straightforward behavioral measures of movements, a measure of global motor activity; holepokes, a measure of investigatory activity; or spatial d, a measure of the structure of locomotor patterns. An increase in d represents an increase in the roughness of the locomotor path, whereas a decrease in d represents an increase in the smoothness of the path. Data are presented as group means \pm SEM for the first 30 min of testing in the BPM.

${ }^{*} p<.05$, group is different from its respective saline control group.

$\# p<.05$, group is different from its respective SAL/treatment group. Experiments 1 and 2 use the same comparisons, as do Experiments 3 and 4 .

${ }^{+}$Significant difference between the respective SAL/LSD and SER/LSD groups.

In the simple behavioral measures themselves (Table 1), SER-082 pretreatment successfully antagonized the effects of DOI on holepokes and on spatial $d$ at the highest dose, but not on movements.

Thus, acute treatment with $0.25 \mathrm{mg} / \mathrm{kg}$ DOI decreased measures of amounts of activity, of exploratory behavior, and of behavioral organization, such that patterns of activity exhibited smoother, more predictable locomotor paths. These effects were only antagonized by the highest dose of SER-082 pretreatment.

\section{EXPERIMENT 3}

\section{Procedure}

A total of 122 rats was pretreated with either saline or $0.25,0.5,1.0$, or $2.0 \mathrm{mg} / \mathrm{kg}$ MDL 100,907. Then rats were treated with either saline or $60 \mu \mathrm{g} / \mathrm{kg}$ LSD. These doses were selected from previous studies (Sipes and Geyer 1995; Krebs and Geyer 1994). The 10 groups $(n=7-27)$ were tested for $60 \mathrm{~min}$.

\section{Results and Discussion}

Based on previous results, these data were examined for the first $30 \mathrm{~min}$ of testing, a time resolution previously used in Experiments 1-2 and in a similar experiment (Mittman and Geyer 1991). There were significant interactions between MDL 100,907 and LSD for the exploratory behavior factor $[\mathrm{F}(4,112)=3.26]$ and the behavioral organization factor $[F(4,112)=12.34]$, indicating that some of the effects produced by $60 \mu \mathrm{g} / \mathrm{kg}$ LSD were affected by MDL 100,907 pretreatment.

Specific comparisons revealed that the acute admin- 


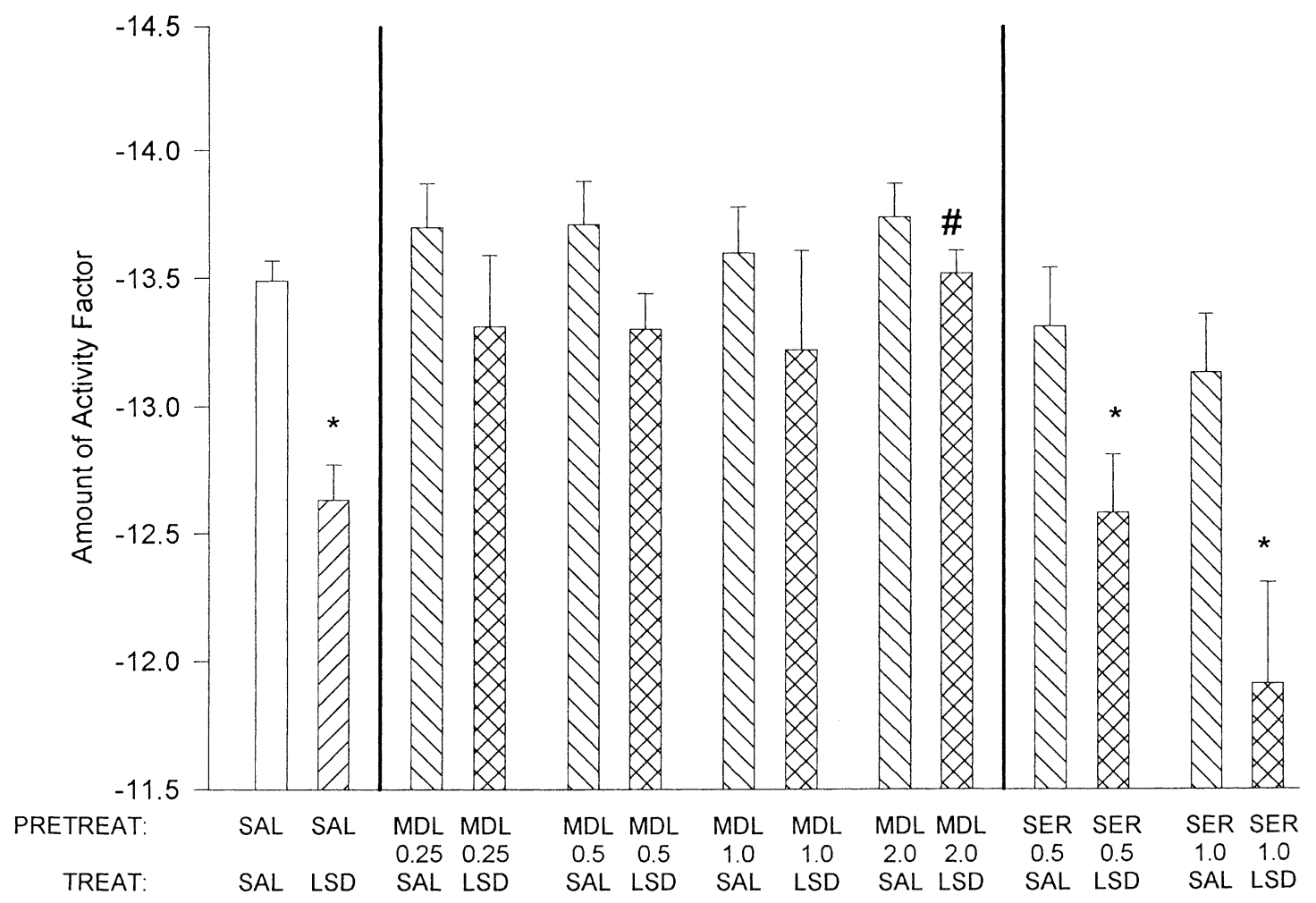

Figure 4. LSD $(60 \mu \mathrm{g} / \mathrm{kg})$ treatment significantly decreased the amount of activity factor, a complex measure of locomotor activity. This decrement was attenuated significantly by $2.0 \mathrm{mg} / \mathrm{kg}$ MDL 100,907 pretreatment, indicating antagonism. Neither dose of SER-082 pretreatment attenuated this effect. Data are presented as group means \pm SEM for the first 30 min of testing in the BPM. ${ }^{*} p<.05$, group is different from its saline control group. $\# p<.05$, group is different from SAL/LSD group.

istration of LSD significantly reduced all three factors in saline-pretreated rats, indicated by the asterisk symbols (Figures 4-6). As in Experiment 1, there was no significant effect of MDL 100,907 alone on any factor. For the amount of activity factor, only the highest dose of MDL 100,907 pretreatment $(2.0 \mathrm{mg} / \mathrm{kg})$ antagonized the effects of LSD. For the exploratory behavior factor, the 0.25 and $1.0 \mathrm{mg} / \mathrm{kg}$ doses of MDL 100,907 appeared to antagonize the effects of LSD, although, given the unusual, non-dose-dependent nature of the interaction (Figure 5), this effect questionable. All doses of MDL 100,907 pretreatment successfully antagonized the effects of LSD on the Behavioral Organization Factor, indicated by the pound symbols in Figure 6 .

In the simple behavioral measures, MDL 100,907 pretreatment antagonized the effects of LSD only on spatial d, indicated by the pound symbols in Table 1 .

Thus, acute treatment with $60 \mu \mathrm{g} / \mathrm{kg}$ LSD decreased measures of amounts of activity, of exploratory behavior, and of behavioral organization, such that patterns of activity exhibited smoother, more predictable locomotor paths. Only the effects of LSD on behavioral or- ganization were robustly antagonized by MDL 100,907 pretreatment.

\section{EXPERIMENT 4}

\section{Procedure}

Eighty-seven rats were pretreated with either saline, 0.5 , or $1.0 \mathrm{mg} / \mathrm{kg}$ SER-082 and treated with either saline or $60 \mu \mathrm{g} / \mathrm{kg}$ LSD. These doses were selected from Experiment 3 and previous studies (Krebs and Geyer 1994; Sipes and Geyer 1995). The six groups $(n=6-27)$ were tested for $60 \mathrm{~min}$.

\section{Results and Discussion}

As in the preceding experiments, these data were examined further for the initial $30 \mathrm{~min}$ of testing. There was a significant interaction between SER-082 and LSD only for the behavioral organization factor $[\mathrm{F}(2,81)=7.81]$, indicating that these effects produced by $60 \mu \mathrm{g} / \mathrm{kg}$ LSD were altered by SER-082 pretreatment. 


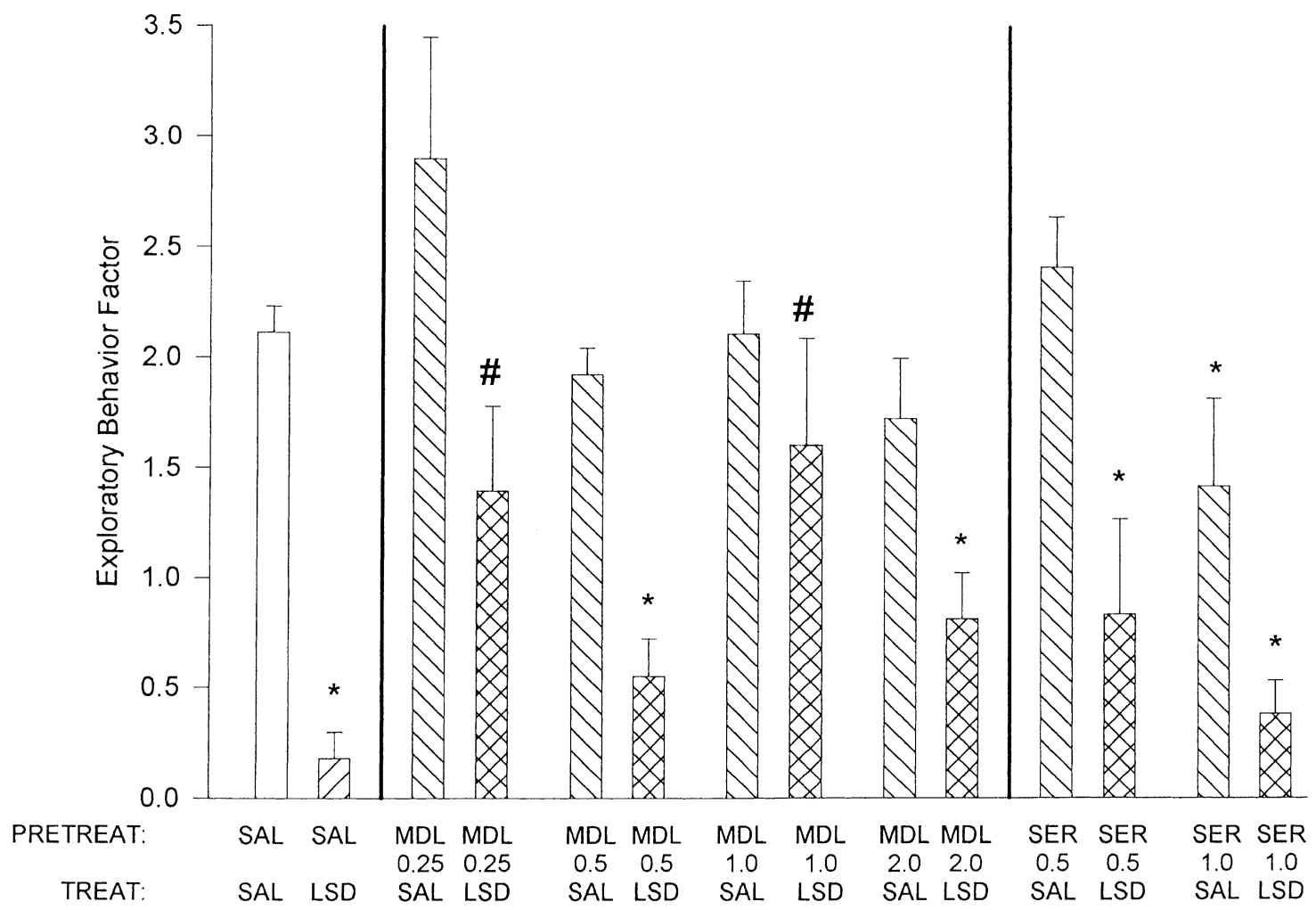

Figure 5. LSD $(60 \mu \mathrm{g} / \mathrm{kg})$ treatment significantly decreased the exploratory behavior factor, a complex measure of investigatory activity. This decrement was attenuated significantly by 0.25 and $1.0 \mathrm{mg} / \mathrm{kg}$ MDL 100,907 pretreatment, indicating a non-dose-dependent antagonism. Neither dose of SER-082 pretreatment attenuated this effect. Data are presented as group means \pm SEM for the first 30 min of testing in the BPM. ${ }^{*} p<.05$, group is different from its saline control group. \# $p<.05$, group is different from SAL/LSD group.

Specific comparisons revealed that there was a significant difference between the $1.0 \mathrm{mg} / \mathrm{kg}$ SER-082pretreated (SER1.0/SAL) group and the SAL/SAL group for the exploratory behavior factor, indicating that there was a significant pretreatment effect of SER082 alone for this measure (Figure 5). There was no antagonism of the effects of LSD on either the amount of activity factor or the exploratory behavior factor by SER-082 pretreatment (Figures 4-5). Conversely, both doses of SER-082 pretreatment successfully antagonized the effects of LSD on the behavioral organization factor, indicated by the pound symbols in Figure 6 .

In the simple behavioral measures, SER-082 pretreatment only antagonized the effects of LSD on spatial d, indicated by the pound symbols in Table 1 . In fact, SER082 pretreatment appeared to potentiate the effects of LSD on movements, evidenced by the significant difference between the respective SAL/LSD and SER/LSD groups, indicated by the plus (+) symbols in Table 1 .

Thus, acute treatment with $60 \mu \mathrm{g} / \mathrm{kg}$ LSD decreased measures of amounts of activity, of exploratory behavior, and of behavioral organization, such that patterns of activity exhibited smoother, more predictable loco- motor paths. Only the effects of LSD on behavioral organization were antagonized by SER-082 pretreatment.

\section{DISCUSSION}

The main results of these investigations were: (1) the effects of the 5- $\mathrm{HT}_{2 \mathrm{~A} / 2 \mathrm{C}}$ agonist DOI on activity, exploratory behavior, and behavioral organization were similar to those produced by the $5-\mathrm{HT}_{1 \mathrm{~A} / 2 \mathrm{~A} / 2 \mathrm{C}}$ agonist LSD; (2) all of these effects produced by DOI were due to $5-\mathrm{HT}_{2 \mathrm{~A}}$ receptor stimulation; and (3) LSD differs from $\mathrm{DOI}$ in the respective roles that $5-\mathrm{HT}_{2 \mathrm{~A}}$ and $5-\mathrm{HT}_{2 \mathrm{C}}$ receptors play in modulating these effects, as the effect of LSD on behavioral organization was attributable to $5-\mathrm{HT}_{2 \mathrm{~A}}$ and $5-\mathrm{HT}_{2 \mathrm{C}}$ receptor stimulation, whereas the effects of LSD on amount of activity and exploratory behavior were not attrubutable to $5-\mathrm{HT}_{2 \mathrm{~A}}$ or $5-\mathrm{HT}_{2 \mathrm{C}}$ receptor stimulation.

Both of these hallucinogens altered measures of the amount of locomotor activity, exploratory behavior, and behavioral organization, such that both hallucinogens produced more predictable locomotor patterns. It 


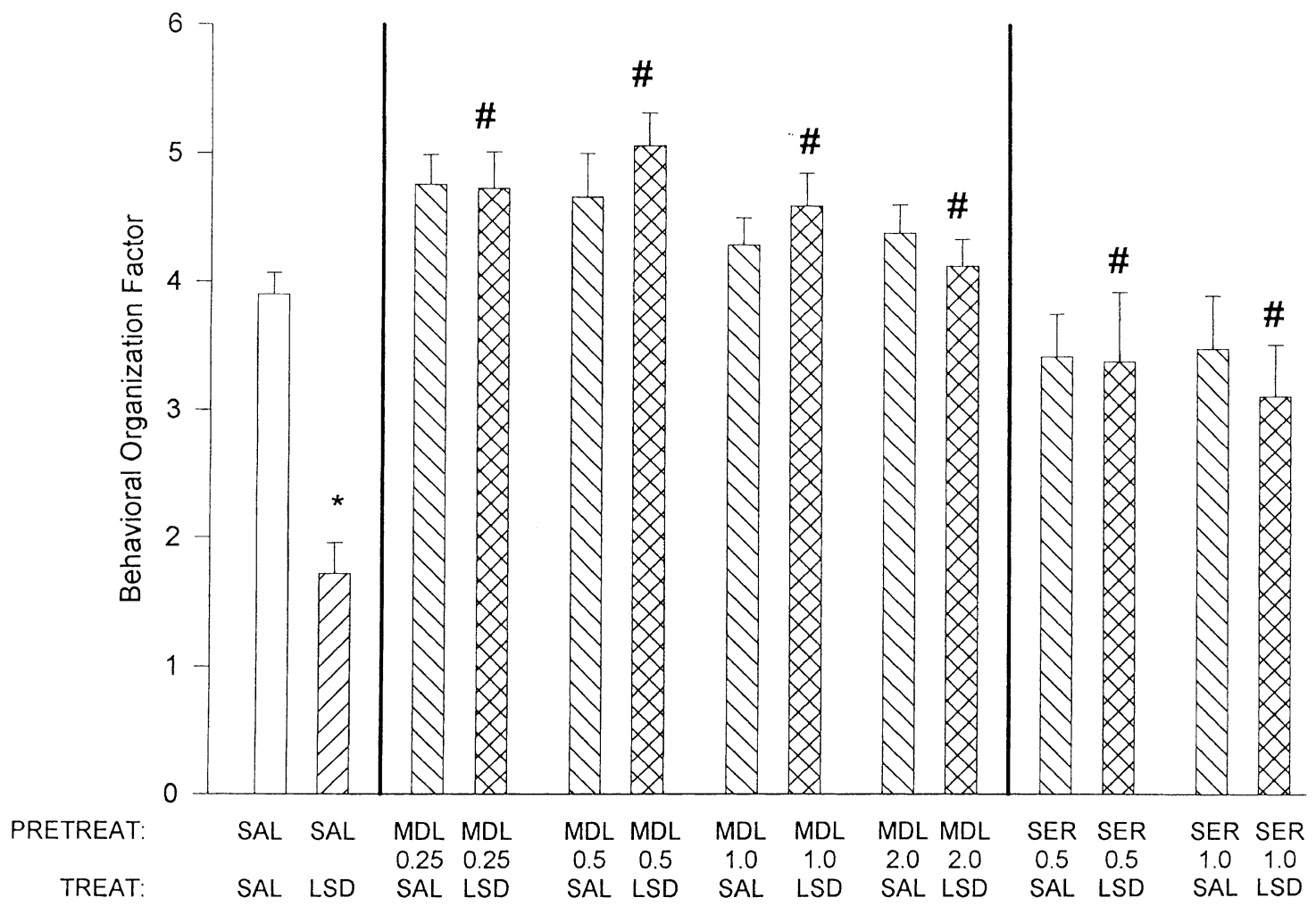

Figure 6. LSD $(60 \mu \mathrm{g} / \mathrm{kg})$ treatment significantly decreased the behavioral organization factor, a measure of the structure of the locomotor pattern. This decrement indicates an increase in the smoothness and predictability of the locomotor pattern. This effect of LSD was attenuated significantly by $0.25,0.5$, or $1.0 \mathrm{mg} / \mathrm{kg}$ MDL 100,907 pretreatment, indicating antagonism. 0.5 and $1.0 \mathrm{mg} / \mathrm{kg}$ SER-082 pretreatments also attenuated this effect. Data are presented as group means \pm SEM for the first 30 min of testing in the BPM. ${ }^{*} p<.05$, group is different from its saline control group. \# $p<.05$, group is different from SAL/LSD group.

appears that use of these three factors for assessing the effects of hallucinogens yields more robust, orderly dose-response effects than observed with more traditional measures of individual responses. These results support the utility of the three-factor model for characterizing different hallucinogens, as evidenced by the following differential interactions with a phenalkylamine and indoleamine hallucinogen. Thus, in the current paradigm DOI and LSD produced similar behavioral profiles.

Nevertheless, selective serotonin antagonists revealed differences in the mechanisms responsible for the effects of DOI and LSD. The effects of DOI were attributable to $5-\mathrm{HT}_{2 \mathrm{~A}}$ receptor stimulation. The effects of DOI on all three factors of behavior were antagonized by even the lowest dose of the $5-\mathrm{HT}_{2 \mathrm{~A}}$ antagonist MDL 100,907 . These results support the findings of MDL 100,907 antagonism of the effects of DOI observed in previous studies, in which other behaviors were examined, such as prepulse inhibition of startle or drug discrimination (Padich et al. 1996; Sipes and Geyer 1995; Schreiber et al. 1994). Thus, 5- $\mathrm{HT}_{2 \mathrm{~A}}$ receptors influence all of the effects of DOI in the BPM.
None of the effects of DOI was due to $5-\mathrm{HT}_{2 \mathrm{C}}$ receptor stimulation. While the effects of DOI on all three factors of behavior were significantly antagonized by the highest dose of the 5- $\mathrm{HT}_{2 \mathrm{C}}$ antagonist SER-082, these results were not weighted as heavily as those observed with MDL 100,907. The selectivity of SER-082, reported to have 40 -fold selectivity for $5-\mathrm{HT}_{2 \mathrm{C}}$ receptors over $5-\mathrm{HT}_{2 \mathrm{~A}}$ receptors and other sites, is not as marked as with MDL 100,907 and there has also been little behavioral testing of this compound for functional selectivity (Nozulak et al. 1995). As the lower dose of SER-082 showed absolutely no antagonism of the effects of DOI, perhaps the higher dose produced antagonism of the effects of DOI because it antagonized $5-\mathrm{HT}_{2 \mathrm{~A}}$ receptors, as well as $5-\mathrm{HT}_{2 \mathrm{C}}$ receptors. Thus, selective antagonism of $5-\mathrm{HT}_{2 \mathrm{C}}$ receptors does not appear to influence the effects of DOI.

The effects of LSD in this paradigm were similar to those produced by DOI but were influenced by different mechanisms. The effects of LSD on behavioral organization were due to $5-\mathrm{HT}_{2 \mathrm{~A}}$ and $5-\mathrm{HT}_{2 \mathrm{C}}$ receptor stimulation, while the effects of LSD on amount of activity and exploratory behavior were influenced by neither 

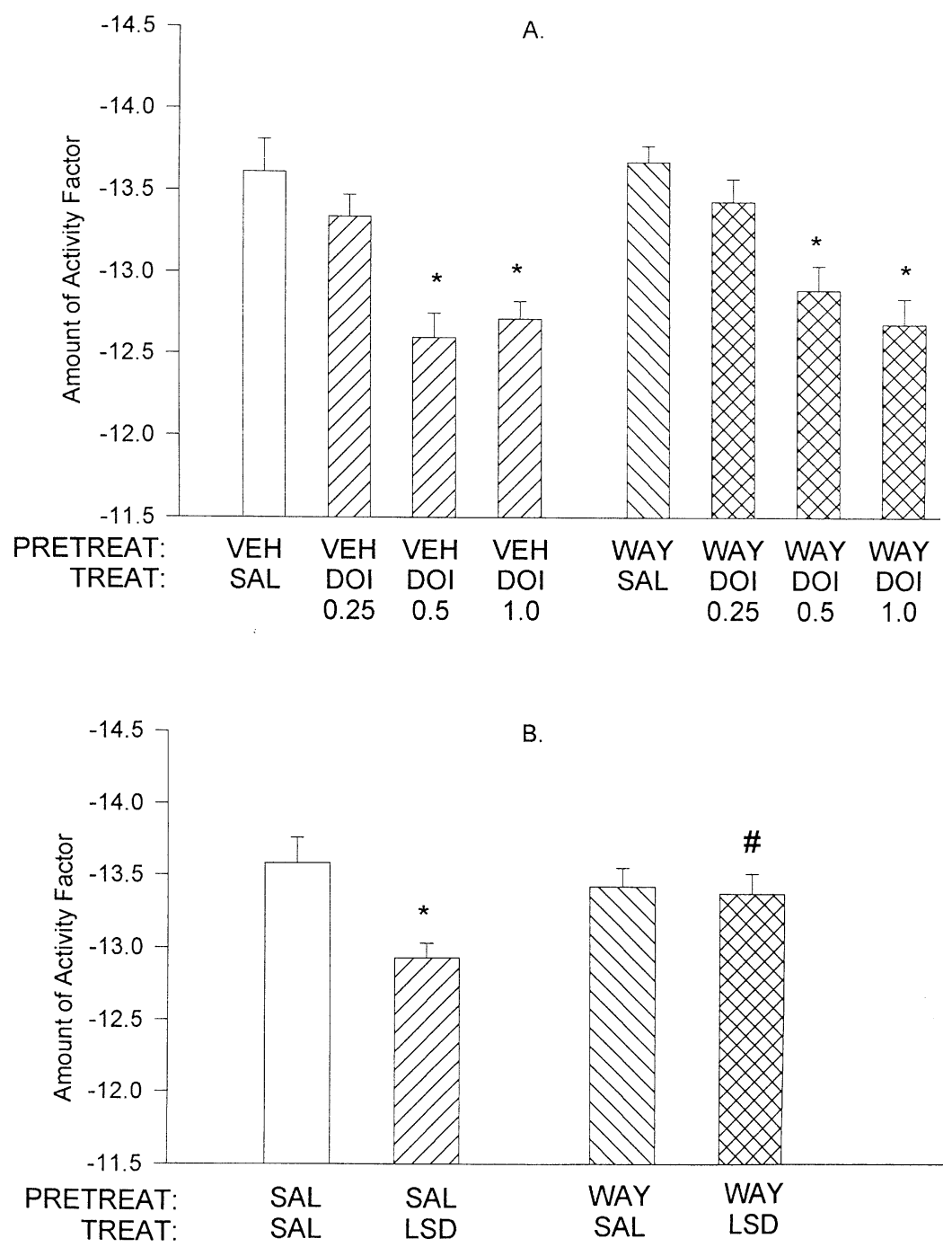

Figure 7. (A) DOI $(0.5-1.0 \mathrm{mg} / \mathrm{kg})$ treatment significantly decreased the amount of activity factor, a complex measure of locomotor activity. This decrement was not attenuated by 1.0 mg/kg WAY-100635 pretreatment. (B) LSD (60 $\mu \mathrm{g} / \mathrm{kg}$ ) treatment also significantly decreased the amount of activity factor. This decrement was attenuated significantly by $1.0 \mathrm{mg} / \mathrm{kg}$ WAY-100635 pretreatment, indicating antagonism. Data are presented as group means \pm SEM for the first 30 min of testing in the BPM. * $p<.05$, group is different from its respective saline control group. \# $p<.05$, group is different from its respective SAL/treatment group. Data were reanalyzed from a previously reported experiment. (Krebs-Thomson and Geyer 1996). Pretreatments and treatments were administered subcutaneously 30 and 10 min prior to testing, respectively. receptor subtype antagonist. The effects of LSD on the amount of activity were not antagonized significantly by MDL 100,907, except at the highest dose of $2.0 \mathrm{mg} / \mathrm{kg}$ MDL 100,907. There did seem to be a slight trend toward antagonism at some of the lower doses, but nothing as marked as with DOI. The effects of LSD on exploratory behavior were antagonized by 0.25 or 1.0 $\mathrm{mg} / \mathrm{kg}$ MDL 100,907 pretreatment, but not by other doses. We have no explanation for this unusual, nondose-dependent antagonism and this effect, if real, should be viewed with some skepticism. The effects of LSD on behavioral organization were robustly antagonized by all doses of MDL 100,907 pretreatment. Thus, some of the effects of LSD appear to be more influenced by $5-\mathrm{HT}_{2 \mathrm{~A}}$ receptors than others. $5-\mathrm{HT}_{2 \mathrm{~A}}$ receptors appear to play the most important role in the effects of LSD on behavioral organization.

The effects of LSD on behavioral organization were also due to $5-\mathrm{HT}_{2 \mathrm{C}}$ receptor stimulation. The effects of LSD on activity and exploratory behavior were not blocked by any dose of the $5-\mathrm{HT}_{2 \mathrm{C}}$ antagonist SER-082. In fact, the effects of LSD on the straightforward measure of activity, movements, shows that both doses of SER-082 pretreatment potentiated these effects of LSD (Table 1). Conversely, the effects of LSD on behavioral organization were antagonized by even the low dose of SER-082 pretreatment. Thus, $5-\mathrm{HT}_{2 \mathrm{C}}$ receptors influence the effects of LSD on behavioral organization, but not on exploratory behavior. As antagonism of $5-\mathrm{HT}_{2 \mathrm{C}}$ receptors actually potentiated some of the effects of LSD on activity only, $5-\mathrm{HT}_{2 \mathrm{C}}$ receptors may have an influence on the effects of LSD on activity in an opposite manner to their effect on other behaviors. This result supports an earlier experiment in which ritanserin pretreatment not only failed to antagonize the initial, locomotor-attenuating effects of LSD, but actually potentiated them (Mittman and Geyer 1991). This result also suggests that ritanserin, a nonselective $5-\mathrm{HT}_{2 \mathrm{~A} / \mathrm{C}}$ antagonist, potentiated those effects of LSD by virtue of its blockade of $5-\mathrm{HT}_{2 \mathrm{C}}$ receptors. 

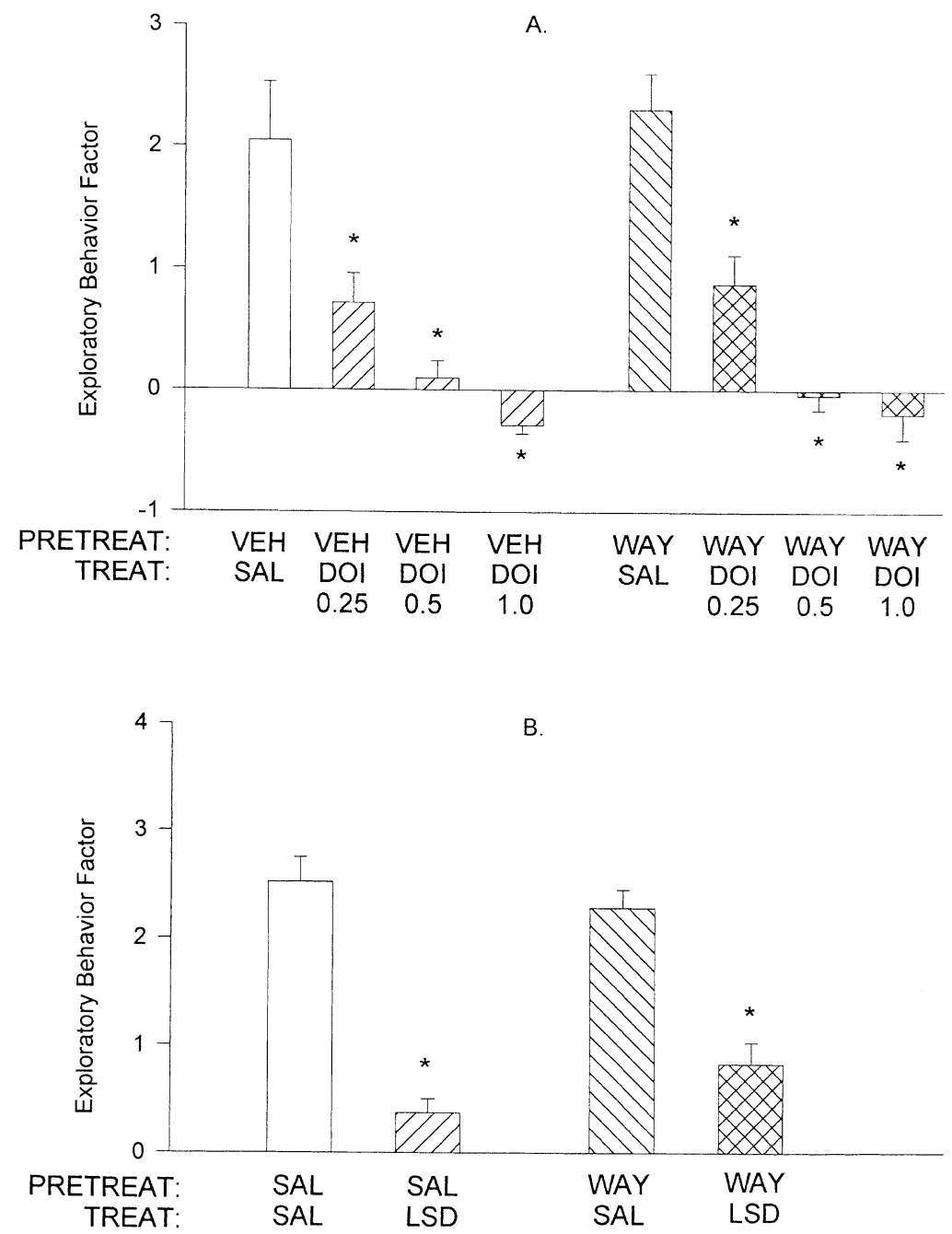

Figure 8. (A) DOI $(0.25-1.0 \mathrm{mg} / \mathrm{kg})$ treatment significantly decreased the exploratory behavior factor, a complex measure of investigatory activity. This decrement was not attenuated by WAY-100635 pretreatment. (B) LSD $(60 \mu \mathrm{g} / \mathrm{kg})$ treatment also significantly decreased the exploratory behavior factor. This decrement was also not attenuated by $1.0 \mathrm{mg} / \mathrm{kg}$ WAY-100635 pretreatment. Data are presented as group means \pm SEM for the first $30 \mathrm{~min}$ of testing in the BPM. $* p<.05$, group is different from its respective saline control group. \# $p<.05$, group is different from its respective SAL/treatment group. Data were reanalyzed from a previously reported experiment (Krebs-Thomson and Geyer 1996). Pretreatments and treatments were administered subcutaneously 30 and $10 \mathrm{~min}$ prior to testing, respectively.
DOI and LSD also differ with respect to the role of $5-\mathrm{HT}_{1 \mathrm{~A}}$ receptors in modulating these effects. The effects of LSD on activity and behavioral organization were influenced by $5-\mathrm{HT}_{1 \mathrm{~A}}$ receptors, while none of the effects of DOI was. As discussed earlier, the prevailing view has been that hallucinogenic drug action is attributable to agonist activity at $5-\mathrm{HT}_{2 \mathrm{~A} / \mathrm{C}}$ receptors (Glennon et al. 1984; Titeler et al. 1988). Because of the indications here that neither $5-\mathrm{HT}_{2 \mathrm{~A}}$ nor $5-\mathrm{HT}_{2 \mathrm{C}}$ receptor activation could account for all of the effects of LSD, other receptor subtypes were investigated. The decreases in locomotor activity produced by LSD were previously attenuated by pretreatment with the selective $5-\mathrm{HT}_{1 \mathrm{~A}}$ antagonist WAY-100635, indicating that these effects of LSD in this paradigm were due to an influence on $5-\mathrm{HT}_{1 \mathrm{~A}}$ receptors (Krebs-Thomson and Geyer 1996). This report, however, only presented measures of horizontal locomotion. To determine if WAY100635 pretreatment would influence the effects of LSD on the three factors of behavior discussed presently, we reanalyzed the data presented in Krebs-Thomson and
Geyer (1996) for both LSD and DOI. As can be seen in Figures 7A-8A, DOI attenuated measures of amounts of activity and exploratory behavior. The decreases in the behavioral organization factor reflect the fact that DOI produced more predictable locomotor paths (Figure $9 \mathrm{~A})$. Antagonism of $5-\mathrm{HT}_{1 \mathrm{~A}}$ receptors had no influence on the effects of DOI for any measure. These results accord with previous results in which WAY100635 failed to attenuate the effects of DOI on locomotion in the BPM (Krebs-Thomson and Geyer 1996). Thus, the effects of DOI on all three factors of behavior, previously shown to be attributable to $5-\mathrm{HT}_{2 \mathrm{~A}}$ receptor influence, were not due to any additional influence of $5-\mathrm{HT}_{1 \mathrm{~A}}$ receptors.

The effects of LSD, however, did appear to be influenced by $5-\mathrm{HT}_{1 \mathrm{~A}}$ receptors. As seen in Figures 7B-9B, LSD attenuated measures of amounts of activity, exploratory behavior, and behavioral organization, which indicates that LSD produced more predictable locomotor paths. Pretreatment with WAY-100635 blocked the effect of LSD on amount of activity (Figure 7B) and be- 

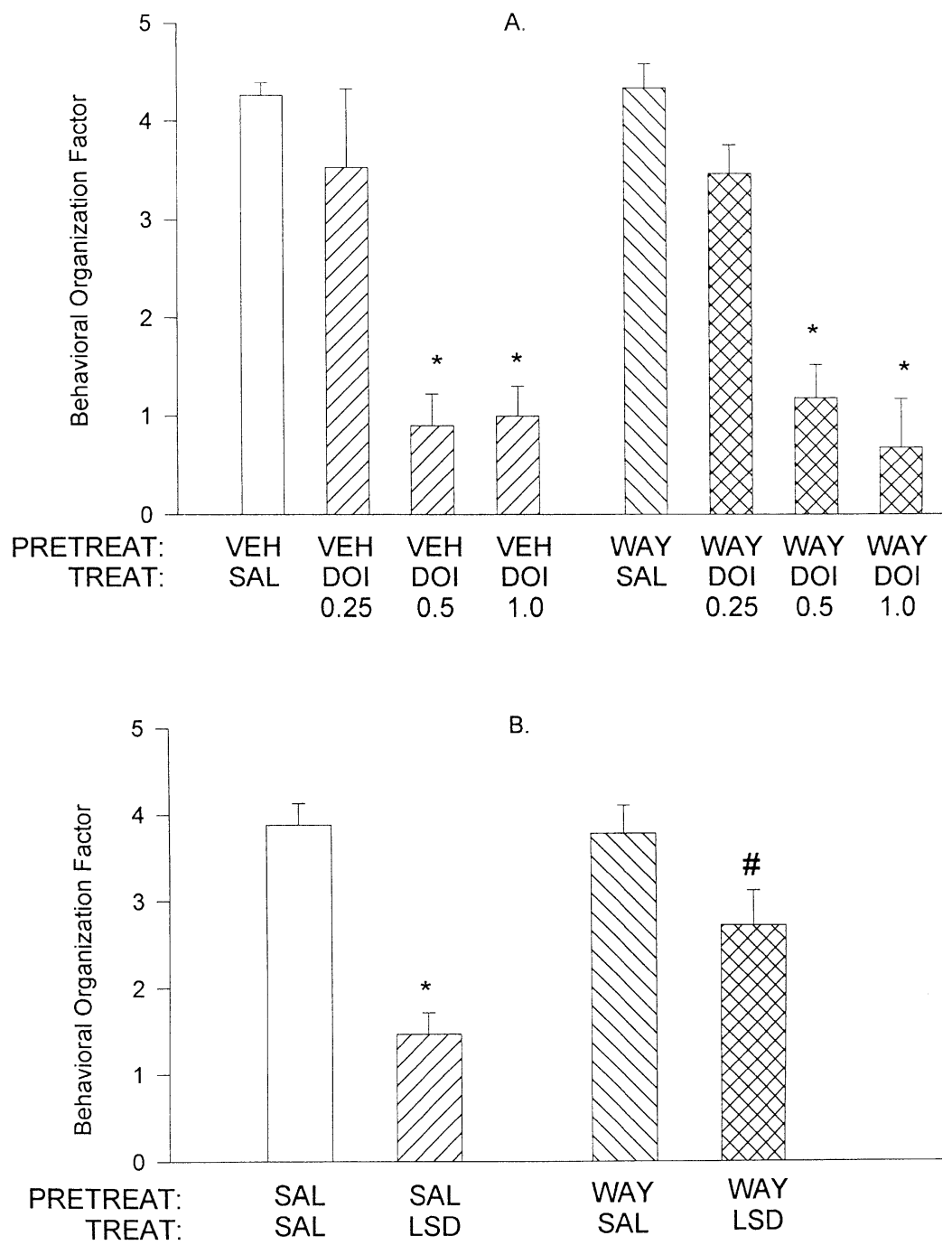

Figure 9. (A) DOI $(0.5-1.0 \mathrm{mg} / \mathrm{kg})$ treatment significantly decreased the behavioral organization factor, a measure of the structure of the locomotor pattern. This decrement indicates an increase in the smoothness and predictability of the locomotor pattern. This decrement was not attenuated by WAY-100635 pretreatment. (B) LSD $(60 \mu \mathrm{g} / \mathrm{kg})$ treatment also significantly decreased the behavioral organization factor. This decrement was significantly attenuated by $1.0 \mathrm{mg} / \mathrm{kg}$ WAY-100635 pretreatment, indicating antagonism. Data are presented as group means \pm SEM for the first $30 \mathrm{~min}$ of testing in the BPM. ${ }^{*} p<.05$, group is different from its respective saline control group. $\# p<.05$, group is different from its respective SAL/ treatment group. Data were reanalyzed from a previously reported experiment (Krebs-Thomson and Geyer 1996). Pretreatments and treatments were administered subcutaneously 30 and $10 \mathrm{~min}$ prior to testing, respectively. havioral organization (Figure 9B), but had no influence on the effect of LSD on exploratory behavior (Figure $8 \mathrm{~B})$. Thus, the effects of LSD on amount of activity, previously shown to be weakly or not at all influenced by either $5-\mathrm{HT}_{2 \mathrm{~A}}$ or $5-\mathrm{HT}_{2 \mathrm{C}}$ receptors, were due to the influence of $5-\mathrm{HT}_{1 \mathrm{~A}}$ receptors. This result accords with a previous study in which pretreatment with WAY-100635 attenuated the effects of LSD on locomotion (KrebsThomson and Geyer 1996). The effects of LSD on exploratory behavior, previously shown to be unusually influenced by $5-\mathrm{HT}_{2 \mathrm{~A}}$ receptors and not at all by $5-\mathrm{HT}_{2 \mathrm{C}}$ receptors, were not due to any additional influence of $5-\mathrm{HT}_{1 \mathrm{~A}}$ receptors. The effects of LSD on measures of behavioral organization, previously shown to be attributable to the influence of both $5-\mathrm{HT}_{2 \mathrm{~A}}$ and $5-\mathrm{HT}_{2 \mathrm{C}}$ receptors, were also due to action at $5-\mathrm{HT}_{1 \mathrm{~A}}$ receptors.

The prevailing view emphasizing the importance of $5-\mathrm{HT}_{2 \mathrm{~A} / \mathrm{C}}$ receptors in the action of hallucinogenic drugs is accurate for the effects of the phenalkylamine $5-\mathrm{HT}_{2 \mathrm{~A} / \mathrm{C}}$ agonist DOI, which are due primarily to action at $5-\mathrm{HT}_{2 \mathrm{~A}}$ receptors, rather than $5-\mathrm{HT}_{2 \mathrm{C}}$ receptors. The effects of DOI on all three factors, including amount of activity, exploratory behavior, and behavioral organization, were sensitive to the antagonism of $5-\mathrm{HT}_{2 \mathrm{~A}}$ receptors. Thus, any of these factors may be helpful in characterizing the effects of a phenalkylamine hallucinogen such as DOI.

The indoleamine hallucinogen LSD is different from DOI in its mechanisms of action. In contrast to the effects of DOI, $5-\mathrm{HT}_{2 \mathrm{~A}}$ receptors do not appear to contribute to the effects of LSD on amount of activity in as robust a manner. It appears that $5-\mathrm{HT}_{1 \mathrm{~A}}$ receptors contribute more to the effects of LSD on activity than do $5-\mathrm{HT}_{2 \mathrm{~A} / \mathrm{C}}$ receptors. $5-\mathrm{HT}_{2 \mathrm{~A}}$ receptors, as well as $5-\mathrm{HT}_{2 \mathrm{C}}$ receptors, do play significant roles in the effects of LSD on the structure of locomotor activity and how this behavior is organized. The effects of LSD on behavioral organization were most sensitive to antagonism of $5-\mathrm{HT}_{2 \mathrm{~A}}$ receptors, as well as of $5-\mathrm{HT}_{2 \mathrm{C}}$ receptors. Thus, it seems as if the behavioral organization measure of the structure of rat locomotor patterns is the most sensitive 
tool with which to characterize the effects of an indoleamine hallucinogen such as LSD.

For future studies, therefore, it appears that behavioral organization, in context of the other factors, may best demonstrate the effects of hallucinogens in the BPM. As well, the importance of the influence of 5- $\mathrm{HT}_{1 \mathrm{~A}}$ receptors to the effects of the hallucinogen LSD is supported by converging evidence and should be kept in mind. The dissociation of the influence of various receptor subtypes on different aspects of the effects of hallucinogens on rat behavior establishes the utility of these three factors for characterizing these drugs.

\section{ACKNOWLEDGMENTS}

This work was supported by National Institute on Drug Abuse Award R02 DA02925. M. A. Geyer was supported by a Research Scientist Award from the National Institute of Mental Health (KO5 MH01223).

\section{REFERENCES}

Adams LM, Geyer MA (1982): LSD-induced alterations of locomotor patterns and exploration in rats. Psychopharmacology 77:179-185

Adams LM, Geyer MA (1985): A proposed animal model for hallucinogens based on LSD's effects on patterns of exploration in rats. Behav Neurosci 99:881-900

Carr AA, Hay DD, Dudley MW, Kehne JH, Nieduzak TR (1991): MDL 28,133A and related $\alpha$-aryl-4-piperidinyl methanols and ketones as potent and selective inhibitors of serotonin 5- $\mathrm{HT}_{2}$ receptors. Abstracts of the IIIrd International Congress on Schizophrenia Research, Tucson, Arizona.

Geyer MA (1990): Approaches to the characterization of drug effects on locomotor activity in rodents. In Adler MW, Cowan A (eds), Modern Methods in Pharmacology: Testing and Evaluation of Drugs of Abuse. New York, Wiley-Liss, pp 81-99

Geyer MA, Krebs KM (1994): Serotonin receptor involvement in an animal model of the acute effects of hallucinogens. In Lin G, Glennon RA (eds), Hallucinogens: An Update. Rockvill, MD, National Institute on Drug Abuse, pp 124-156

Glennon RA, Titeler M, McKenney JD (1984): Evidence for 5-HT2 involvement in the mechanism of action of hallucinogenic agents. Life Sci 35:2505-2511
Johnson MP, Siegel BW, Carr AA (1996): [ $\left.{ }^{3} \mathrm{H}\right]$ MDL 100,907: A novel selective $5-\mathrm{HT}_{2 \mathrm{~A}}$ receptor ligand. NaunynSchmiedeberg's Arch Pharmacol 354:205-209

Kehne JH, Baron BM, Carr AA, Chaney SF, Elands J, Feldman DJ, Frank RA, van Giersbergen PL, McCloskey TC, Johnson MP, McCarty DR, Poirot M, Senyah Y, Siegel BW, Widmaier C (1996): Preclinical characterization of the potential of the putative atypical antipsychotic MDL 100,907 as a potent $5-\mathrm{HT}_{2 \mathrm{~A}}$ antagonist with a favorable CNS safety profile. J Pharmacol Exp Ther 277:968-981

Krebs KM, Geyer MA (1994): Cross-tolerance studies of serotonin receptors involved in behavioral effects of LSD in rats. Psychopharmacology 113:429-437

Krebs-Thomson K, Geyer MA (1996): The role of $5-\mathrm{HT}_{1 \mathrm{~A}}$ receptors in the locomotor-suppressant effects of LSD: WAY-100635 studies of 8-OH-DPAT, DOI, and LSD. Behav Pharmacol 6:551-559

Mittman SM, Geyer MA (1991): Dissociation of multiple effects of acute LSD on exploratory behavior in rats by ritanserin and propranolol. Psychopharmacology 105:69-76

Nozulak J, Kalkman HO, Floersheim P, Hoyer D, Schoeffter P, Buerki HR (1995): (+)-cis-4,5,7a,8,9,10,11,11a-Octahydro$7 \mathrm{H}$-10methylindol[1,7-bc][2,6]-naphthyridine: $\mathrm{A} 5 \mathrm{HT}_{2 \mathrm{C} / 2 \mathrm{~B}}$ receptor antagonist with low $5-\mathrm{HT}_{2 \mathrm{~A}}$ receptor affinity. J Med Chem 38:28-33

Padich RA, McCloskey TC, Kehne JH (1996): 5-HT modulation of auditory and visual sensorimotor gating: II. Effects of the 5- $\mathrm{HT}_{2 \mathrm{~A}}$ antagonist MDL 100,907 on disruption of sound and light prepulse inhibition produced by 5-HT agonists in Wistar rats. Psychopharmacology 124: $107-116$

Palfreyman MG, Schmidt CJ, Sorenson SM, Dudley MW, Kehne JH, Moser P, Gittos MW, Carr AA (1993): Electrophysiological, biochemical and behavioral evidence for 5-HT2 and 5-HT3 mediated control of dopaminergic function. Psychopharmacology 112:S60-S67

Paulus MP, Geyer MA (1993): Three independent factors characterize spontaneous rat motor activity. Behav Brain Res 53:11-20

Schreiber R, Brocco M, Millan MJ (1994): Blockade of the discriminative stimulus effects of DOI by MDL 100,907 and the "atypical" antipsychotics, clozapine and risperidone. Eur J Pharmacol 264:99-102

Sipes TE, Geyer MA (1995): DOI disruption of prepulse inhibition of startle in the rat is mediated by $5-\mathrm{HT}_{2 \mathrm{~A}}$ and not by $5-\mathrm{HT}_{2 \mathrm{C}}$ receptors. Behav Pharmacol 6:839-842

Titeler M, Lyon RA, Glennon RA (1988): Radioligand binding evidence implicates the brain 5-HT2 receptor as a site of action for LSD and phenylisopropylamine hallucinogens. Psychopharmacology 94:213-216 